\title{
Changes in Soil Microflora Following Application of Fungicides Dyrene and Maneh to Tropical Soils ${ }^{1}$
}

\author{
H. D. Dubey and Rita L. Rodriguez ${ }^{2}$
}

\section{INTRODUCTION}

The fungicides Dyrene, 2,4-dichloro-6-(o-chloroaniline)-s-triazine and Maneb, manganese ethylene bisdithiocarbamate, are applied frequently to tomato crops grown in rotation with sugarcane on the south coast of Puerto Rico. As many as 20 to 30 applications each of $3 \mathrm{lb} / \mathrm{A}$ of Dyrene, Maneb, and Zineb, ${ }^{3}$ zinc ethylene bisdithiocarbamate, amounting to 60 to $90 \mathrm{lb} / \mathrm{A}$ of these three chemicals are often applied to a field in one season. In view of such heavy applications it is important to know what their effect may be on soil microorganisms as these play significant roles in biological cycles influencing the availability of plant nutrients in the soil. A nutritional problem which developed in sugarcane on the south coast of the Island was attributed recently to a disturbance in the soil biology apparently brought about by heavy applications of pesticides to the preceding tomato crop (1). As fungicides are also microbiocides, their application to the field may likewise affect the incidence of soilborne plant pathogens by upsetting the microbiological equilibrium in the soil. Research conducted in the laboratory of the Agricultural Experiment Station (2) has shown that Dyrene and Maneb inhibit the ammonia oxidizing bacteria but not the nitrite oxidizing bacteria, and that Maneb is several times more toxic to these organisms than Dyrene. At high concentrations of these fungicides ammonification is also inhibited.

With these considerations in mind, an experiment was conducted over an 18-month period to determine the immediate and long-term effects of Dyrene and Maneb on microorganisms in two agriculturally important soils of the Island. The results are presented in this paper.

\section{EXPERIMENTAL PROCEDURE}

Two widely different soil types were used in the study: (a) San Anton loam, an alkaline fertile loam from the southern coast of the Island which

1 Manuscript submitted to Editorial Board July 3, 1973.

- Associate Soil Microbiologist and Research Assistant, respectively, Department of Agronomy and Soils, Agricultural Experiment Station, Mayagüez Campus, University of Puerto Rico, Río Piedras, P.R.

- Trade names are used in this publication solely for the purpose of providing specific information. Mention of a trade name does not constitute a guarantee or warranty of equipment or materials by the Agricultural Experiment Station of the University of Puerto Rico or an endorsement over other equipment or materials not mentioned. 
is the principal sugarcane growing region of Puerto Rico, and (b) Humatas clay, an acid lateritic soil from the central humid region used for growing coffee. Some important characteristics of these soils are given in table 1. Soil samples were collected from 0 - to an 8-inch depth from virgin sites and used immediately after screening through a $2.0 \mathrm{~mm}$ soil sieve to remove roots, stones, and larger soil particles.

The soils were treated with $0,60,240$, and $960 \mathrm{ppm}$ (active ingredient) of Dyrene and Maneb. Wettable powder formulations were applied as water suspension by an atomizer over 500-g soil samples spread as a thin layer on a plastic sheet, and uniformly mixed with the soil. The samples were transferred to $1000 \mathrm{ml}$ Erlenmeyer flasks and enough distilled water

TABLE 1.-Some characteristics of the soils used

\begin{tabular}{|c|c|c|c|c|c|c|c|}
\hline \multirow{2}{*}{ Soil type } & \multirow{2}{*}{$\mathrm{pH}$} & \multirow{2}{*}{$\begin{array}{l}\text { Percent } \\
\text { organic } \\
\text { matter }\end{array}$} & \multirow{2}{*}{$\begin{array}{l}\text { Cation } \\
\text { exchange } \\
\text { capacity } \\
\text { me/100 g. }\end{array}$} & \multicolumn{3}{|c|}{ Texture (percent) } & \multirow{2}{*}{ Clay type } \\
\hline & & & & Sand & Silt & Clay & \\
\hline Humatas clay ${ }^{1}$ & 5.0 & 4.8 & 13.2 & 4 & 37 & 59 & Kaolinite \\
\hline San Anton loam² & 7.7 & 5.1 & 34.1 & 42 & 33 & 25 & $\begin{array}{l}\text { Mixture of kao- } \\
\text { linite and } \\
\text { montmorillo- } \\
\text { nite }\end{array}$ \\
\hline
\end{tabular}

1 Acid lateritic soil receiving 100 inches of rainfall; highly leached soil; poor fertility. According to 7th approximation-Typhic Tropohumult, clayey, kaolinitic, isohyperthermic.

2 Alluvial soil from river flood plain; semi-arid receiving 40 inches of rainfall; most fertile soil of the Island. According to 7th approximation-Cumulic Haplustoll, fine-loamy, mixed, isohyperthermic.

was added to bring the soil to field capacity moisture. The flasks were capped with "Parafilm" to avoid the escape of moisture and still allow gaseous exchange. The flasks were incubated in the laboratory at $23 \pm$ $1^{\circ}$ C. After 2, 4, 8, and 16 weeks, and after 10, 15, and 18 months, soil samples were taken from the flasks for microbial count by the dilution plate technique. Ten-gram samples (oven-dry basis) were used to prepare the dilution series. Five plates were poured from the dilution used for plating. Each treatment was replicated twice. Moisture was determined at each sampling date. There was practically no loss of moisture up to 8 weeks, but sampling at later dates showed slight moisture loss. This was corrected by adding distilled water to the incubating soil cultures.

For bacterial and actinomycete counts, 1:100,000 dilutions were used and for fungi the dilutions were 1:1,000. Sodium albuminate agar medium was used for bacteria and actinomycetes and Rose Bengal agar medium 
with streptomycin for fungi. The plates for microbial count were incubated at $23^{\circ} \pm 1^{\circ} \mathrm{C}$ for 7 days before making counts.

After 15 months of incubation, 100-g samples from soil cultures which had received $960 \mathrm{ppm}$ of the chemicals, were transferred to $250 \mathrm{ml}$ Erlenmeyer flasks, and 5-g samples of freshly collected soils from the Humatas and the San Anton soils were mixed with the corresponding soils, and left to incubate for an additional period of 3 months. Microbial counts of the control and the $960 \mathrm{ppm}$ treatments with and without soil inoculant were then recorded. The objective was to determine if the effect of excessive amounts of these chemicals on the soil microbes can be rectified by inoculation with fresh untreated soil.

\section{RESULTS}

Changes in the number of microorganisms with time in the Humatas and the San Anton soils following applications of Dyrene and Maneb are shown in figures 1, 2, and 3. Population curves of the untreated soils show that the two very different soils used in the study did not markedly differ in the relative bacterial numbers present. This may be due to the fact that in neither of these soils was the $\mathrm{pH}$ (table 1) very favorable for bacterial proliferation. Fungi were more abundant in the Humatas, probably because the acidic $\mathrm{pH}$ of this soil favored growth of fungi more than that of bacteria and actinomycetes. Slightly higher numbers of actinomycetes in the Humatas soil may be due to the presence of some acid-tolerant strains in this soil.

\section{BACTERIA}

Dyrene application resulted in an increase of the bacterial number (fig. 1). In the San Anton soil, the increases with a rise in the levels of Dyrene were almost proportional to the amount of Dyrene applied, and the peak population was attained earlier than in the Humatas. After reaching a peak, the bacterial population decreased gradually so that after 10 months practically no difference existed between the untreated and treated soils.

Maneb application also resulted in an increase in the bacterial number (fig. 1). In the San Anton soil, the increase was proportional to the level of Maneb application as was the case after Dyrene application. The bacterial number reached the peak soon after Maneb application and then went down to normal after 10 months at all rates of application except at $960 \mathrm{ppm}$. At this high rate the bacterial number remained markedly higher than the control even at 18 months after treatment. The $960 \mathrm{ppm}$ of Maneb caused the greatest bacterial proliferation in both soils. The bacterial number in the Humatas soil was, however, unaffected up to $240 \mathrm{ppm}$, but at $960 \mathrm{ppm}$ of Maneb it was markedly increased. 

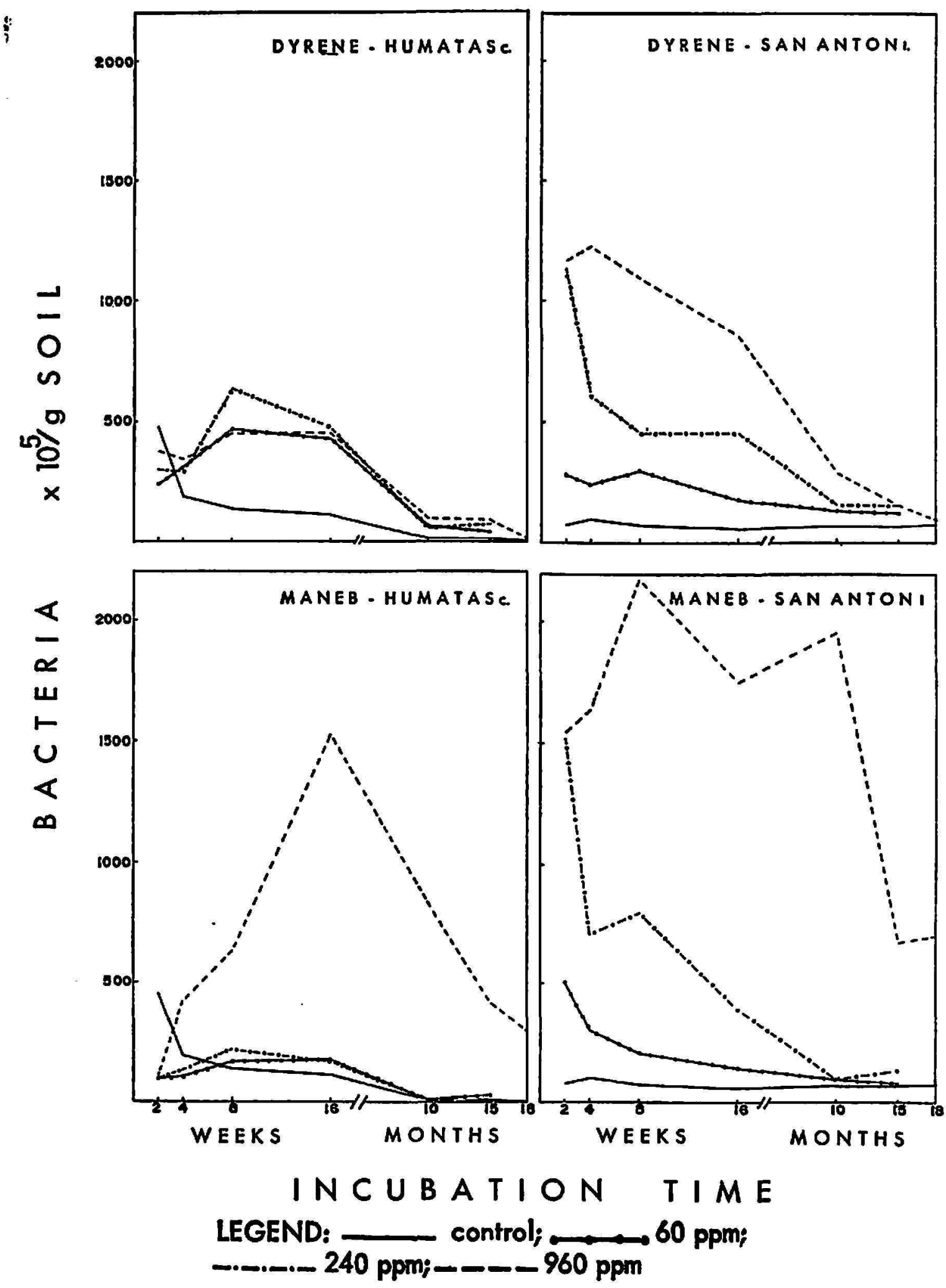

Fro. 1.-Changes in the bacterial number with time in the Humatas clay and the San Antón loam soils following application of Dyrene and Maneb. 


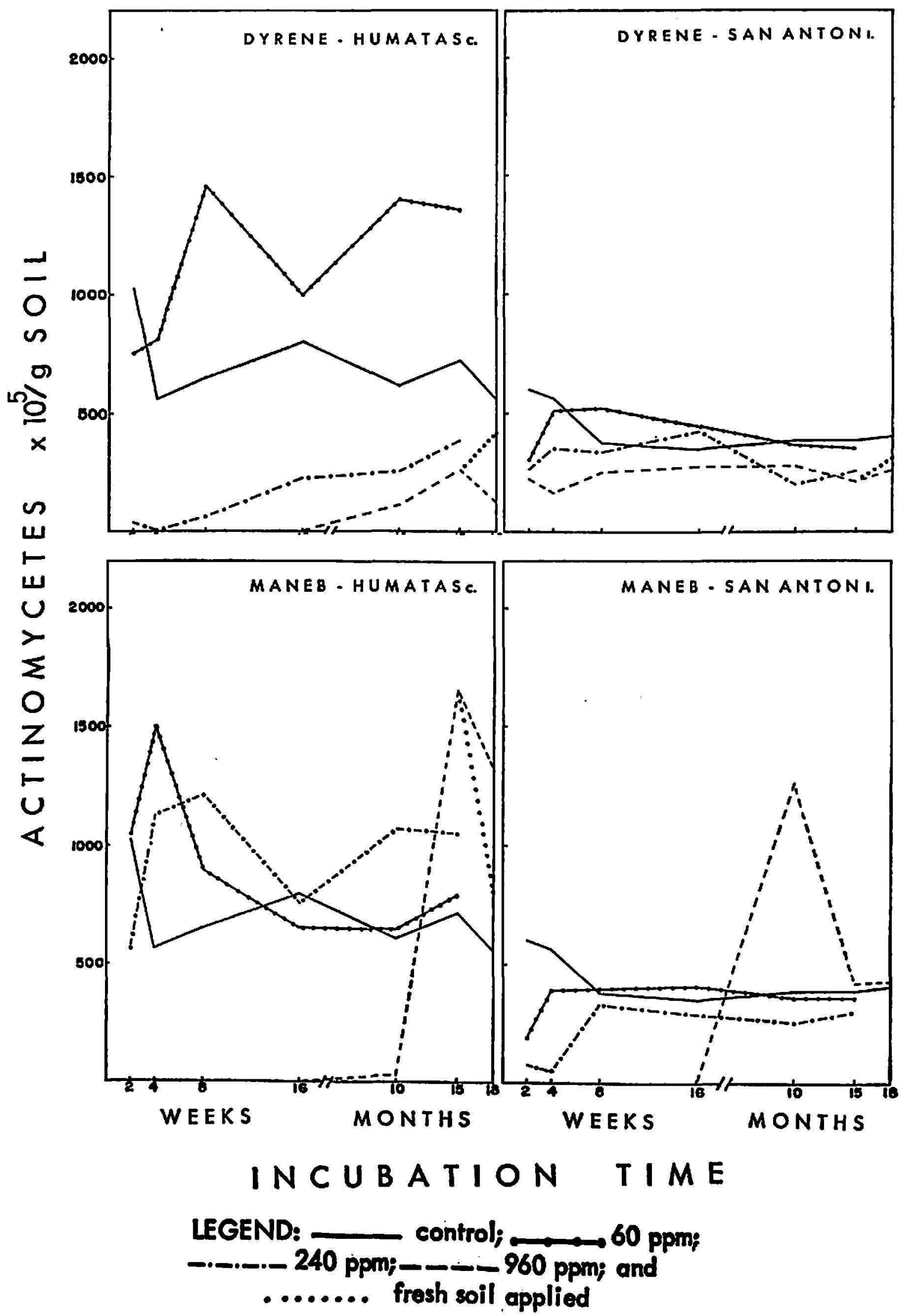

Fre. 2.-Changes in the number of actinomycetes with time in the Humatas clay and the San Antón loam soils following application of Dyrene and Maneb. 

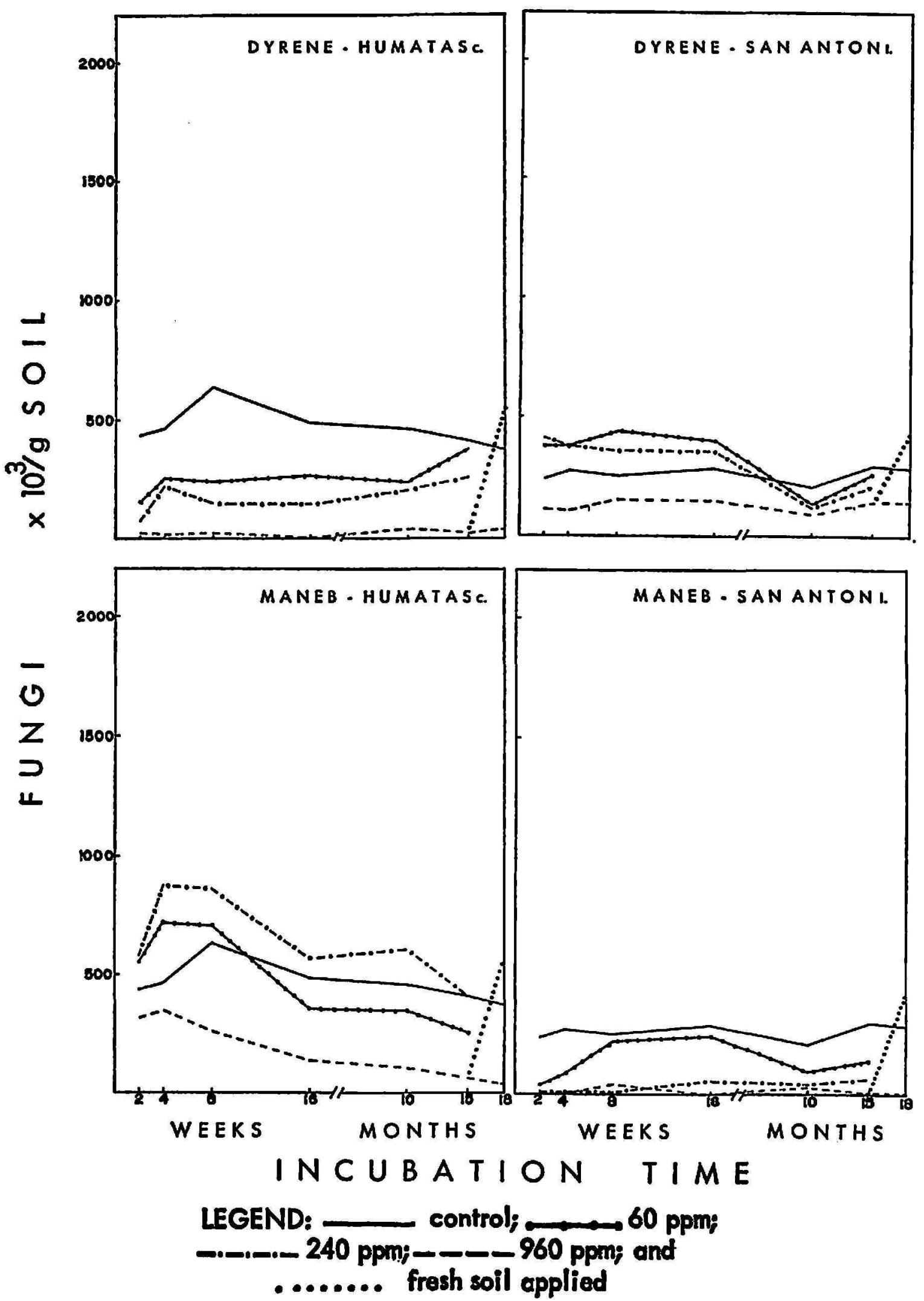

FrG. 3.-Changes in the number of fungi with time in the Humatas clay and the San Antón loam soils following application of Dyrene and Maneb. 


\section{ACTINOMYCETES}

The effect of Dyrene and Maneb on the actinomycete numbers in the two soils are shown in figure 2. The fungicides caused an initial depression of the actinomycetes in both soils immediately after application (2-week observation). Subsequently, the actinomycetes in the Humatas soil were increased at $60-\mathrm{ppm}$ Dyrene but were decreased at $240 \mathrm{ppm}$ and above. In the San Anton soil the actinomycetes were depressed only at the highest rate of Dyrene, $960 \mathrm{ppm}$. At lower levels of Dyrene their number was not affected.

Effect of Maneb on the actinomycete number in the two soils was somewhat similar to that of Dyrene. At $960 \mathrm{ppm}$ it definitely depressed the actinomycetes in both soils. At lower levels, in the Humatas soil there was a tendency for an increase early during incubation ( 4 to 8 weeks) but no later effect. Lower levels of Maneb did not show any effect in the San Anton soil except for the initial depression immediately after application of the fungicide.

The depressing effect of the $960 \mathrm{ppm}$ rate of the two fungicides on the actinomycetes appeared to be rectified in both soils following inoculation with fresh soil.

\section{FUNGI}

Changes in the number of fungi in the two soils following application of Dryene and Maneb appear in figure 3. Fungi in the Humatas soil showed a decrease at all levels of Dyrene application. The inhibition was persistent throughout the period of study and was almost proportional to the quantity of the chemical applied. In the San Anton soil only $960 \mathrm{ppm}$ of Dyrene caused a persistent decrease in the fungi. At lower levels Dyrene resulted in an increase in the number of fungi for a period of 16 weeks but the number came down to near normal later.

Maneb up to $240 \mathrm{ppm}$ did not affect the fungi, but depressed them at $960 \mathrm{ppm}$ in Humatas soil. In the San Anton soil increasing rates of Maneb showed distinct and persistent inhibition of the fungi.

The inhibition of the fungi resulting from Dyrene or Maneb applications was offset by inoculation of the treated soils with fresh soil (fig. 3). In addition to quantitative changes, application of Maneb resulted in qualitative changes in the soil fungi. Only three kinds-Penicillium spp., Aspergillus spp., and Trichoderma spp.-were found in soils receiving high rates of Maneb.

\section{DISCUSSION}

Simazine has been reported $(3,5)$ to have no stimulating effect on soil bacteria. However, Dyrene, also a triazine compound, showed distinct stimulation of the soil bacteria in the present study. 
Both Dyrene and Maneb resulted in a decrease of the actinomycetes and fungi. The effect of Dyrene was more pronounced in Humatas soil and that of Maneb in San Anton soil. Strains of actinomycetes and fungi present in the highly leached acidic Humatas soil apparently were more susceptible to Dyrene, and those in the alkaline San Anton soil more so to Maneb.

The earlier reports of inhibition of fungi by triazine compounds such as Atrazine (4) and Simazine (M. L. DeVries, Ph.D. thesis. Univ. of Wisconsin, 1962) seem to be supported by the present observation with Dyrene.

Tolerance of Aspergillus spp., Penicillium spp., and Trichoderma spp., to Maneb in the present study confirms some of the findings of earlier workers $(5,6)$ wherein these molds were reported to be among the most resistant fungi against different kinds of fungicides.

The reduction of the actinomycetes and fungi resulting from applications of high rates of Dyrene and Maneb was offset by inoculation with fresh soil. This indicates the possibility that in case of an accidental heavy application of these fungicides to a localized spot in a field, the harmful effect on the soil microorganisms can be rectified by the application of fresh soil or manure to the affected area followed by plowing. As manure is much richer than soil in microbial population it may be applied in much smaller quantities to remedy the problem.

Because the two chemicals invariably stimulated bacteria and inhibited actinomycetes and fungi, especially at higher rates, the data suggests that the bacteria are the microorganisms principally responsible for utilizing or degrading both fungicides in the soil.

The differential response of the microorganisms in the two soils to a particular chemical may be indicative of the presence there of different strains of the microorganisms. This is quite possible as these soils are very different in their characteristics.

\section{SUMMARY}

Changes in soil microorganisms following applications of 2,4-dichloro6-(o-chloroaniline)-s-triazine (Dyrene) and manganese ethylene bisdithiocarbamate (Maneb) at $0,60,240$, and $960 \mathrm{ppm}$ to the acid lateritic $\mathrm{Hu}$ matas clay and the alkaline fertile San Anton loam incubated at $23^{\circ} \pm 1^{\circ}$ C were studied for 18 months in the laboratory.

In general, bacterial numbers increased and actinomycetes and fungi decreased especially at higher concentrations of the chemicals. The bacterial increase disappeared at the 10-month count but persisted longer at the $960 \mathrm{ppm}$ rate of Maneb. Bacteria seem to be the principal microorganisms responsible for degradation of these fungicides in the soil. Maneb caused qualitative as well as quantitative changes in the fungal population. Microorganisms in the two soils differed in their response to the chemical 
treatment. Inhibition of the microorganisms was offset by inoculation with fresh soil.

\section{RESUMEN}

Durante 18 meses se estudiaron, en condiciones de laboratorio, los cambios producidos en los microorganismos presentes en el suelo arcilloso ácido laterítico Humatas y en el alcalino y fértil San Antón lómico, ambos incubados a $23^{\circ} \pm 1^{\circ} \mathrm{C}$. después de haber recibido aplicaciones de 2,4dicloro-(o-cloroaniline)-s-triazina (Dyrene) y etileno bisditiocarbamato de manganeso (Maneb) en concentraciones de 0, 60, 240 y 960 p.p.m.

En general, el número de bacterias aumentó y el de actinomicetos y hongos disminuyó, especialmente a las concentraciones más altas de los agentes químicos. El aumento en el número de bacterias cesó a los 10 meses, excepto en el caso del Maneb a 960 p.pm., cuando el incremento persistió por más tiempo. Parecen ser las bacterias los principales microorganismos responsables de la degradación de estos fungicidas en el suelo. El Maneb produjo cambios cuantitativos y cualitativos en la población de hongos. En cuanto a la reacción al tratamiento químico, se notaron diferencias entre los microorganismos de uno y otro suelo. La inoculación con suelo fresco neutralizó la inhibición de los microorganismos.

\section{LITERATURE CITED}

1. Dubey, H. D., A nitrogen deficiency disease of sugarcane probably caused by repeated pesticide applications, Phytopathology 60: 485-7, 1970.

2. - , and Rodriguez, R. L., Effect of Dyrene and Maneb on nitrification and ammonification, and their degradation in tropical soils, Soil Sci. Soc. Amer. Proc. 34: 435-9, 1970.

3. Eno, C. F., The effect of Simazine and Atrazine on certain of the soil microflora and their metabolic processes, Soil and Crop Sci. Soc. Florida 22: 49-56, 1962.

4. Guillemat, J., Charpentier, M., Tardieux, P., and Pochon, J., Interactions between a chloro-amino-triazine herbicide and fungal and bacterial microflora of soil (in French), Annales des Epiphytes 11: 261-94, 1960.

5. Messiaen, C. M., and Lafon, R., Comparative efficiency of various dithiocarbamates in treatments of seeds or bulbs on the soil fungi. (in French), PhytiatriePhytopharm. 10: 89-92, 1961.

6. Young, P. A., Soil fumigation with chloropicrin and carbon disulfide to control tomato root knot and wilt, Phytopathology 30: 860-5, 1940. 